SEÇÃO LIVRE 



\title{
Trabalhadores e liberdade - a abolição da escravidão e as comemorações de 1888
}

Renata Figueiredo Moraes*

Resumo: este texto discute a participação de trabalhadores livres nos festejos pela abolição da escravidão realizados na Corte. Entre eles estão funcionários públicos, tipógrafos e caixeiros. Enquanto os primeiros tiveram o privilégio da folga para celebrar a liberdade dos escravos, os caixeiros precisaram acionar os jornais para reivindicar a participação na festa. Essa dificuldade, de certo modo, estava ligada à própria condição vivida por eles no seu cotidiano de trabalho. Por outro lado, os tipógrafos se viam como trabalhadores importantes para a lei, por terem também atuado na sua confecção gráfica, podendo facilmente celebrar a abolição através de préstitos e confecção de jornais especiais. Apesar do 13 de Maio inaugurar um novo momento no mundo do trabalho, ainda era preciso eliminar algumas relações de dependência e precariedade vivida por trabalhadores livres.

Palavras-chave: abolição; festa; trabalhadores livres.

\begin{abstract}
: this paper discusses the participation of free workers in the festivities for the abolition of slavery in Rio de Janeiro. Among them are civil servants, printers and clerks. While the formers had a day off to celebrate the freedom of slaves, the clerks had to drive the newspapers to claim participation in the party. This difficulty was, to a certain extent, the very condition experienced daily by those workers. Furthermore, the printers could easily celebrate the abolition through processions and manufacture of special papers. They often saw themselves as indispensable to the abolition, because they had been active in his graphic production. Despite the May 13 opened a new era in the world of work, it was still necessary to eliminate some relations of dependency and insecurity experienced by free workers.
\end{abstract}

Keywords: abolition; festivities; free workers.

\section{Introdução}

A lei da abolição, assinada em 13 de maio de 1888 no Rio de Janeiro, provocou uma euforia festiva patrocinada e organizada pela imprensa da Corte que, a seu modo, indicou quais festejos e quando deveria ser comemorado o

* Professora adjunta de História do Brasil - UERJ. E-mail: renatafm2003@yahoo.com.br. 
fim da escravidão. O entusiasmo daqueles dias tomou conta de toda a cidade e não foi diferente entre aqueles que já eram trabalhadores livres. Todos queriam testemunhar a grande vitória e o início de um novo tempo de liberdade. Nas folhas diárias que circulavam na Corte, os assuntos que tomavam conta das suas páginas versavam sobre os efeitos daquela conquista e também dos seus responsáveis. Quem não tinha acesso a esses meios tentava participar de algum modo daquele processo. Uma maneira foi através da contribuição de uma quantia para a compra da pena de ouro usada pela Princesa Isabel. Nessa subscrição, vários grupos de abolicionistas, anônimos ou não, divulgaram seu entusiasmo pela abolição. ${ }^{1}$ Entre eles estavam trabalhadores que organizaram listas em seus locais de trabalho e nelas informaram qual seria o significado da abolição para eles. ${ }^{2}$ Além de participar de um ritual, muitos queriam também frequentar a festa e testemunhar os signos que estavam sendo compartilhados por literatos e pela imprensa. No entanto, a participação nos festejos não foi tão simples como para literatos e funcionários da imprensa. Desse modo, este artigo tem como objetivo tratar de alguns grupos de trabalhadores livres que participaram da festa e que de algum modo interpretaram aquele tempo de liberdade, o fim da escravidão, como algo que pudesse afetar também suas próprias relações de trabalho. Através dessa discussão será possível pensar o trabalho livre nos tempos do Império, assim como o impacto do fim da escravidão para o mundo do trabalho pós-abolição.

\section{Trabalhadores em festa}

O fim da escravidão permitiu que diversos trabalhadores de várias categorias se juntassem aos festeiros da imprensa na comemoração pelo surgimento de um novo tempo de liberdade. Esse conceito tão estranho naqueles tempos de escravização também necessitava de uma definição maior para aqueles que viviam em outras prisões. Uma delas é a respeito do trabalho e sua baixa valorização. $\mathrm{O}$ trabalho livre também tinha suas próprias dificuldades que se agravavam diante de um ambiente escravista e de forte hierarquia no mundo do trabalho. Desse modo, participar das festas da liberdade era também se inserir numa dinâmica de luta e de reivindicação de outros direitos. Uma delas, naquele momento, era por conquistar espaços na festa e por horas livres de lazer, uma vez que a Corte e seu funcionamento tenderam a permanecer inalterados apesar dos festejos, que pareciam incorporar todo o cotidiano dos seus moradores e do comércio. Diante de tamanha movimentação e demandas que alcançavam toda uma gama de trabalhadores, pedir folgas naquele tempo parecia querer atrapalhar o bom funcionamento da festa. De qualquer modo, essa reivindicação ocorreu a partir de alguns grupos e seu sucesso dependeu do campo de atuação desses profissionais.

Entre os trabalhadores livres e suas hierarquias havia os funcionários públicos, os mais privilegiados naquele momento. Eram, em parte, trabalhadores da burocracia que, ao longo da década de 1880, atuaram na execução da lei de 1871 e nos limites da liberdade e do cativeiro que seus artigos expunham. $O$ funcionalismo público não era uma carreira regulamentada apesar de ser um local

1 MORAES, Renata Figueiredo. "Uma pena de ouro para a Abolição: a lei do 13 de maio e a participação popular". Revista Brasileira de História, São Paulo, 2013, v. 33, n. 66, pp. 49-69.

2 Além de trabalhadores livres, houve também uma mobilização por parte de moradores de regiões mais afastadas da Corte que pretendiam fazer parte dos festejos que se organizavam. MORAES, Renata Figueiredo. "A abolição no Brasil além do parlamento: as festas de maio de 1888". In: CASTILHO, Celso Thomas; MACHADO, Maria Helena P. T. (orgs). Tornando-se livre. Agentes históricos e lutas sociais no processo de abolição. São Paulo: Editora da Universidade de São Paulo, 2015, pp. 315-334. 
de aquisição de uma renda fixa, além de prestígio social, uma vez que estavam acima dos demais trabalhadores livres do período, como caixeiros, artesãos e agregados, por exemplo. ${ }^{3}$

Além de um prestígio maior diante dos outros trabalhadores, o funcionalismo público também era uma alternativa para aqueles homens das letras que, para complementar sua renda, recorriam à burocracia enquanto não conseguissem sobreviver na Corte apenas a partir dos seus textos. O jornalismo e o funcionalismo público foram funções exercidas por Artur Azevedo e Machado de Assis que em 1888 atuavam no Ministério da Agricultura. ${ }^{4}$

Machado de Assis trabalhava no ministério responsável pela realização das matrículas dos escravos, ${ }^{5}$ prevista na lei de setembro de $1871 .^{6} \mathrm{Em} 1888$, o ministro era Rodrigo Silva, também responsável pela apresentação do projeto da lei da abolição à Câmara. ${ }^{7}$ Às vésperas do início dos festejos, ele foi homenageado por seus funcionários na ocasião da sua chegada ao setor na manhã do dia 16 de maio. ${ }^{8}$ O chefe da seção, Machado de Assis, comandou a homenagem com um discurso destacando as ações de Rodrigo Silva e, ao término da sua fala, declarou a admiração sentida por todos ali presentes pela última ação empreendida por ele: o referendo dado à "lei que declarou para sempre extinta a escravidão no Brasil". ${ }^{9}$

Ao final da cerimônia, que contou também com a banda do Arsenal de Guerra, o ministro discursou agradecendo a homenagem, mas lembrou também que o mérito cabia igualmente aos funcionários daquele setor. O fato é que, desde muito antes de Rodrigo Silva assumir o cargo, foi nesse ministério, mais especificamente na segunda seção chefiada por Machado de Assis desde 1876, que o trabalho de cumprimento da lei de 1871 foi feito de forma mais rígida, apesar dos protestos dos donos de escravos que procuravam meios de perpetuar a escravização de homens e mulheres, apesar das novas medidas de regular as relações senhor-escravo a partir de 1871.

A manhã especial da quarta-feira no Ministério da Agricultura terminou com a leitura de uma poesia feita por Artur Azevedo no verso de um cartão de visita:

Conselheiro, perdoai tanta ousadia, Minha falta esqueçai, se há n'isso falta; Mas vós, firmando a lei que a pátria exalta Fizestes igualmente uma poesia,

3 CÂNDIDO, Antônio. Um funcionário da Monarquia. Ensaio sobre o segundo escalão. Rio de Janeiro: Editora Ouro Sobre Azul, 2002, p. 11.

4 MAGAlHÃES JR, Raimundo. Artur Azevedo e sua época. Rio de Janeiro: Civilização Brasileira, 1966, p. 56, especialmente o capítulo "O pé de boi do Ministério".

5 CHALHOUB, Sidney. Machado de Assis, historiador. São Paulo: Companhia das Letras, 2003, p. 207. Machado de Assis ingressou como amanuense, em 1873, no Ministério da Agricultura, Comércio e Obras Públicas, aos 33 anos de idade. Naquela ocasião já era escritor de certo renome tendo publicado alguns livros. No mesmo ano foi nomeado para o cargo de "primeiro oficial". MAGALHÃES JR, Raimundo. Machado de Assis, funcionário público (No Império e na República). Rio de Janeiro: Ministério da Viação e Obras Públicas Serviço de Documentação, 1958, p. 16.

6 A Lei de 1871 estabeleceu a matrícula geral de todos os escravos do Império com declaração de nome, sexo, estado, ofício e filiação, além da criação do Fundo de Emancipação, alimentado por doações, impostos e multas e que serviria para a compra da liberdade de escravos. Além disso, assegurou o direito do escravo em formar pecúlio, para que isto pudesse servir na compra da sua alforria.

7 O deputado Rodrigo Silva assumiu o Ministério em maio de 1887 na ocasião da saída de Antonio Prado. MORAES, Evaristo de. A campanha abolicionista (1879-1888). Brasília: Editora Universidade de Brasília, 1986, p. 144.

8 “Abolição", Gazeta de Notícias, 17 de maio de 1888. O Diário de Notícias e o Cidade do Rio também publicaram a notícia da homenagem a Rodrigo Silva.

9 “Abolição", Gazeta de Notícias, 17 de maio de 1888. 
É muito natural que n'este dia, Que de prazer as almas sobressalta, Os prosaicos ofícios tenham alta; E entrem as musas na secretaria.

Os mesmos sentimentos delicados Que hoje dão direito a honrada lenda, Oh! Providência dos escravizados!

Apelo e o vosso coração nos atenda! Estendei para os vossos empregados A mão que a liberdade referenda!10

Os versos de Artur Azevedo ironizam a liberdade referendada por Rodrigo Silva ao mesmo tempo em que exaltam a importância do seu ato. Por isso, Artur Azevedo e os demais funcionários se apresentam como dignos de receber uma "liberdade" - nesse caso, a folga nos dias seguintes, período de festejos pela Corte, que também, em parte, eram organizados por ele. O pedido de liberação se justificava por ser aquele momento vivido por todos como algo único na história do país e ainda tendo sido prenunciado por um dos membros desse setor. Ou seja, a participação nas festas era uma manifestação de civismo da qual não pretendiam se ausentar. A resposta de Rodrigo Silva foi positiva ao pedido feito em forma de verso e com um "até segunda" liberou seus funcionários para curtir os dias de comemoração. ${ }^{11}$

Rodrigo Silva também liberou do trabalho na repartição aqueles que, mesmo atuando próximos a Machado de Assis e Artur Azevedo (ambos trabalhavam na imprensa da Corte e participaram ativamente da organização das festas da imprensa), não estavam tão comprometidos com essas comemorações. Apesar disso, esses outros trabalhadores tiveram suas atuações reconhecidas numa nota do editor do Cidade do Rio para justificar as homenagens recebidas não apenas por Rodrigo Silva, mas por todos que ao lado dele atuaram.

No silêncio do gabinete, José Júlio, Amarillo de Vasconcelos, Machado de Assis, Pinto Serqueira, Paula Barros, e ainda outros, dedicaram-se durante anos a velar com solicitude na defesa dos direitos dos escravos, a tirar das leis de liberdade todos os seus naturais corolários, a organizar e a tornar efetiva a emancipação gradual pela ação do Estado (...). ${ }^{12}$

Ao citar o nome daqueles que, no cumprimento de suas funções, haviam se dedicado à defesa dos "direitos dos escravos" - expressão reveladora do sentido político de suas ações -, o jornal mostrava como muitos daqueles funcionários da secretaria haviam efetivamente trabalhado para o fim da escravidão ao regularem as relações entre senhor e escravo a partir dos princípios previstos na lei de 1871, que previa, dentre outras medidas, a matrícula de todos os escravizados. ${ }^{3}$ É o que mostra, em especial, o caso de Machado de Assis, chefe da seção encarregada de acompanhar a aplicação da lei de $1871 .{ }^{14}$ Os pareceres escritos por ele para os casos previstos na lei mostram a crença na sua validade

\footnotetext{
10 "Abolição", Gazeta de Notícias, 17 de maio de 1888. Essa poesia também foi publicada por Magalhães Júnior em sua biografia de Artur Azevedo. MAGALHÃES JR. Artur Azevedo e sua época, p. 147.

11 Gazeta de Notícias, 17 de maio de 1888.

12 "Manifestação honrosa", Cidade do Rio, 18 de maio de 1888.

13 CHALHOUB, Sidney. Visões da liberdade. Uma história das últimas décadas da escravidão na corte. São Paulo: Companhia das Letras, 1990.

14 CHALHOUB. Machado de Assis, historiador, p. 138.
} 
como um passo importante para a emancipação dos escravos. Além desse seu trabalho contra a manutenção da escravização de homens e mulheres não matriculados, o literato também utilizava, nesse período, o campo da crônica para elogiar os efeitos da legislação. ${ }^{15}$

O engajamento de funcionários públicos como Machado de Assis na causa dos escravos explica, portanto, o sentido, tanto da homenagem oferecida ao ministro quanto a folga que lhes foi permitida, uma vez que esses trabalhadores eram vistos como agentes daquilo que se festejava em maio de 1888 . A liberdade conquistada com a abolição, fruto também de uma lei, deveria ser festejada por aqueles que, décadas atrás, já vinham lutando pela aplicação de outra medida legislativa e pela preservação dos direitos dos escravos. Em 13 de maio, esse direito tinha sido alcançado na sua plenitude não como uma dádiva, como faziam crer alguns editores dos jornais da Corte, mas como uma conquista iniciada no Parlamento e na Justiça.

A atuação de outros grupos pelo fim da escravidão, longo caminho que não havia sido iniciado apenas em 1888, justificava o pedido de folgas para a vivência da festa e até mesmo a sua realização a partir de outros objetivos. Sendo assim, não apenas os funcionários do Ministério da Agricultura se sentiam responsáveis por percorrer esse caminho; existiam outros que, a seu modo, se sentiam participantes do ato que deu fim à escravidão.

\section{Os tipógrafos}

Os tipógrafos, assim como os funcionários públicos, eram trabalhadores letrados e de influência significativa no mundo da imprensa uma vez que tinham a posse dos instrumentos necessários para a impressão de um jornal. Por conta disso, folhas especiais ligadas a essa categoria circulavam no Rio de Janeiro desde meados do século XIX. Através delas tratavam dos problemas do ofício e reivindicavam melhores condições de vida e de trabalho. $O$ auge dessas reivindicações aconteceu em 1858 quando fizeram uma grande greve, paralisando a circulação dos jornais diários. ${ }^{16}$ Essa greve foi resultado da formação, cinco anos antes, da Associação Tipográfica Fluminense, uma sociedade de auxílio mútuo que servia para ajudar os tipógrafos em caso de necessidade e também para lutar por seus direitos. A mobilização desses trabalhadores, e também o fácil acesso que tinham aos meios da imprensa, permitia que pudessem divulgar em folhas periódicas dedicadas aos seus pares as condições de trabalho em que viviam a fim de fazerem maiores reivindicações e continuarem mobilizados. ${ }^{17}$ Dentre essas folhas estava a Revista Typographica, impressa pela Tipografia Universal de Laemmert \& Cia. Com a abolição, eles se mobilizaram para promover seus próprios festejos e interpretar aquele momento vivido por todos os trabalhadores.

Em maio de 1888, os tipógrafos também atuaram na impressão da lei assinada pela Princesa Regente. Tal fato não foi esquecido naqueles dias de celebração, nos quais tudo que era ligado à imprensa e à abolição transformava-se em motivo de festa. Por esta razão, os nomes de Manoel Germano Brandão e Américo José Leite

15 CHALHOUB. Machado de Assis, historiador, pp. 288-289.

16 VITORINO, Artur José Renda. "Processo de trabalho, sindicalismo e mudança técnica: o caso dos trabalhadores gráficos em São Paulo e no Rio de Janeiro, 1858-1912”. (Dissertação de mestrado, Unicamp, 1995), p. 79.

17 Segundo Marcelo Badaró, os tipógrafos tinham mais condições de divulgar suas ideias por terem acesso à impressão dos jornais. MATTOS, Marcelo Badaró. Escravizados e livres. Experiências comuns na formação da classe trabalhadora carioca. Rio de Janeiro: Bom Texto, 2008, p. 56. 
Pereira foram saudados por terem sido os que compuseram a letra da lei, e o de Joaquim da Cunha Telles por ter sido seu impressor. ${ }^{18}$

A celebração do ato de impressão da lei e dos seus sujeitos foi feita em dois jornais. Na edição do dia 15 de maio, a Gazeta da Tarde descreveu com detalhes a emoção da produção da lei e os trabalhadores daquele momento. A Revista Typographica também registrou de forma sucinta, mas não menos interessante, uma parte do ritual e seus responsáveis. O relato de ambos os periódicos indica, no entanto, outros sentidos para aquele ato além daqueles já pregados pelos jornais. A Revista fez questão de destacar o valor da participação desses profissionais para o futuro da pátria:

Os dois distintos artistas devem sentir verdadeiro orgulho por terem sido os destinados a gravarem em tipos o decreto sublime, que veio riscar da nossa pátria a abominável instituição da escravidão. ${ }^{19}$

A ênfase sobre a participação desses trabalhadores pretendia marcar a presença de mais agentes trabalhando pela abolição além daqueles que atuaram no Senado e na imprensa. Por isso, as saudações recebidas por eles se assemelhavam àquelas recebidas pelos homens do Parlamento.

Ao cair a forma no prelo para tirar a primeira prova para a revisão foi o antigo tirador de provas Manoel Joaquim da Cunha Teles felicitado por seus companheiros de trabalho (...) a suprema ventura de ser o primeiro a imprimir em letra de forma, a diamantina lei que apagava para sempre da bandeira nacional a negra mancha da escravidão; oferecendoIhe nessa ocasião o administrador, o Sr. Antônio Nunes Galvão uma saudação, assinada pela maioria dos empregados presentes, como uma indelével recordação de tão fausto acontecimento debaixo de uma estrondosa salva de palmas. ${ }^{20}$

Ainda que fossem modestas essas louvações, se comparadas àquelas recebidas pela Princesa ou pelos parlamentares, esse relato da Gazeta da Tarde mostra o quanto o ritual da confecção da lei era importante para aquele grupo de trabalhadores - que, ao saudar seus pares que participavam do ato também se reconheciam como parte ativa daquela vitória. O destaque dado aos nomes dos impressores da lei marcava que, de alguma forma, havia a atuação de outros agentes no processo que deu fim à escravidão. Para eles, a participação desses tipógrafos deveria ser ressaltada como sendo a de trabalhadores que contribuíram efetivamente para o fim do que eles chamaram de "negra mancha da escravidão", num caminho semelhante ao dos trabalhadores do serviço público.

Antes mesmo da assinatura da lei, a classe tipográfica já pretendia fazerse presente nos festejos e, assim, garantir um lugar na memória histórica da abolição. ${ }^{21}$ Para os tipógrafos, aquele momento era marcado pelo fim do drama da

18 "As festas da liberdade", Gazeta da Tarde, 15 de maio de 1888 e "A áurea lei”, Revista Typographica, 19 de maio de 1888.

19 “A áurea lei”, Revista Typographica, 19 de maio de 1888.

20 "As festas da liberdade", Gazeta da Tarde, 15 de maio de 1888. De acordo com Artur Vitorino, o trabalho exercido pelos tipógrafos demandava técnica e especialização. Talvez por isso, nesse relato, os compositores, responsáveis pela produção da letra são chamados de artistas pelo editor do jornal. VITORINO, Artur José Renda. "Os sonhos dos tipógrafos na corte imperial brasileira". In: BATALHA, Cláudio H. M.; SILVA, Fernando Teixeira da; FORTES, Alexandre (orgs.). Culturas de classe: Identidade e diversidade na formação do operariado. Campinas: Editora da Unicamp, 2004, p. 174.

21 Gazeta da Tarde, 13 de maio de 1888. Vale ressaltar que a expressão "classe tipográfica" foi utilizada pelos próprios para a convocação dos trabalhadores. 
escravidão e também pela participação de todas as classes, apesar de possuírem características distintas das demais:

Todas as classes, sem distinção, ruidosamente aplaudem esse desfecho, e nós, os homens do progresso, representantes da rainha das artes, devemos fazer ecoar no mundo inteiro as nossas estrondosas palmas.22

Mesmo o discurso tendo uma lógica de que todos os trabalhadores participaram daquele grande desfecho, os tipógrafos pareciam pertencer a uma categoria acima, uma vez que se autodenominaram "homens do progresso". $\mathrm{Na}$ verdade, há muito pretendiam se diferenciar dos demais trabalhadores livres ao se definirem como artistas e detentores de um ofício especializado e, por isso, distintos daqueles que não conheciam as letras e que, por isso, não tinham domínio das técnicas que levariam ao progresso. ${ }^{23}$ Além disso, eram os responsáveis pela produção de uma arte que ultrapassava as fronteiras da Corte. Diante das comemorações pela abolição, os tipógrafos pretendiam ser mais que apenas espectadores. Logo, à medida que foram importantes para a confecção material da lei, deveriam também participar de forma ativa, assim como os homens da imprensa, daqueles festejos que começavam.

O modo pelo qual tratam, em um mesmo movimento, de celebrar o ato da abolição e de se diferenciar do conjunto mais amplo dos trabalhadores da Corte, mostrava as ambiguidades do envolvimento desta categoria com a causa da abolição. Tais ambiguidades já se haviam feito notar nas décadas anteriores, quando o tema entrou na pauta da categoria. Em 1858, por exemplo, houve uma mobilização dos editores do Jornal dos Typógraphos contra os leilões de escravos ocorridos em praça pública. Na ocasião, eles propuseram a criação de uma associação para arrecadar fundos para libertar os escravos que, uma vez libertos, deveriam prestar serviços à associação a fim de compensar o valor pago por eles. ${ }^{24}$ Outros tinham uma solução para reduzir a distância entre eles e os escravos causada pelas décadas de escravização: a instrução noturna e gratuita para os libertos promovida pelo Clube Abolicionista Gutemberg - destinado também a comprar alforrias. ${ }^{25}$ Tal postura deixava claro que, para eles, a eliminação da distinção jurídica dos homens só seria de fato válida se acompanhada de um movimento de instrução dos antigos cativos. ${ }^{26}$ Por mais que não se considerassem iguais aos afrodescendentes que carregavam consigo as marcas da experiência escrava, apontavam, assim, para um caminho de inclusão - capaz de permitir a superação das marcas do atraso que, a seus olhos, explicava a superioridade que julgavam ter sobre eles. Era a educação, do seu ponto de vista, que marcava a diferença. Entretanto, havia outras associações de tipógrafos que sequer permitiam homens de cor em seus quadros de sócios. Se em 1888 faziam questão de afirmar sua participação na luta pela liberdade, desde muito antes já vinham afirmando a superioridade do trabalho qualificado que exerciam diante dos demais trabalhadores livres e, consequentemente, dos escravizados. Assim, partindo de uma clara diferenciação em relação aos demais

22 Gazeta de Notícias, 14 de maio de 1888.

23 MATTOS. Escravizados e livres, p. 196. Essa autodenominação e essa diferenciação tem origem na primeira mobilização dos tipógrafos em torno do Jornal dos Typógraphos, publicação da época da greve de 1858.

24 Jornal dos Typógraphos, 18 de janeiro de 1858, apud VITORINO. Processo de trabalho, sindicalismo e mudança técnica, p. 79-81.

25 MATTOS. Escravizados e livres, pp. 157-8. O autor destaca ainda a promoção por parte dos tipógrafos de conferências de Vicente de Souza, abolicionista, republicano e líder das ideias socialistas, no final da década de 70.

26 VITORINO. Processo de trabalho, sindicalismo e mudança técnica, p. 83. 
trabalhadores, os tipógrafos trataram, naquelas décadas, de dar forma à sua luta.

Percebe-se, com isso, que os tipógrafos, inseridos nas discussões do seu tempo sobre abolicionismo e progresso, participaram do movimento em prol da liberdade dos escravos através de critérios próprios, forjados a partir de suas experiências. No momento da assinatura da lei de 13 de maio, trataram-na como uma vitória pela qual também se viam como responsáveis e, assim, se inseriram nos eventos programados pela imprensa. Um desses eventos foi a realização de um préstito que, ao longo do trajeto, acabaria por se incorporar ao da imprensa, o que mostrava a adesão dos tipógrafos àquela celebração. ${ }^{27}$ Ainda assim, faziam questão de manter sua autonomia: o estandarte da classe e o distintivo na roupa, símbolo individual de pertencimento à categoria, marcariam para os espectadores do desfile quem eram eles em meio ao grande desfile. ${ }^{28}$

Os cerca de 800 tipógrafos que desfilaram no préstito do dia 20 de maio fizeram o percurso passando em cada tipografia existente no caminho a fim de saudar seus semelhantes e aumentar o número de participantes. ${ }^{29}$ Além do desfile, os tipógrafos também escreveram sobre a abolição e distribuíram para quem os assistia poesias e jornais. Entre as poesias estava a de Joaquim Osório DuqueEstrada, "Depois da noite", que foi recitada na passagem do préstito em frente à redação da Revista llustrada. ${ }^{30}$

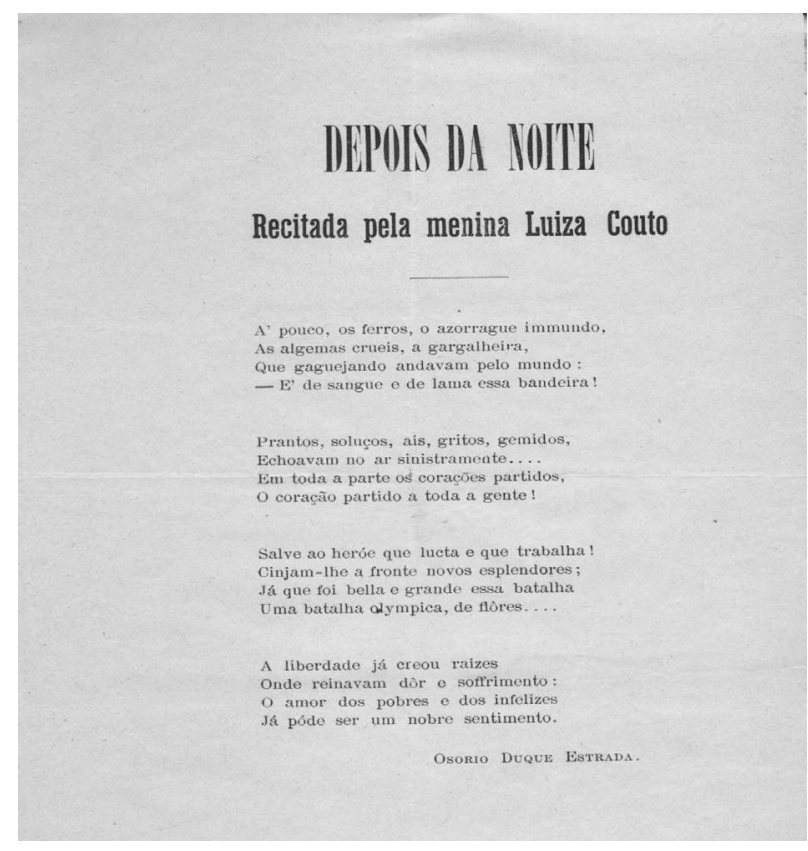

Figura 1 - "Depois da noite”, Osório Duque-Estrada. FONTE: Panfletos abolicionistas. O 13 de maio em versos. Renato Pinto Venâncio (org).

27 A imprensa da Corte organizou os festejos da abolição, que começaram no dia 17 de maio, com uma missa campal e nos dias seguintes foram realizados eventos esportivos, bailes públicos e dois grandes préstitos: um feito por alunos dos colégios da Corte e outro por homens da imprensa e de diferentes setores da sociedade. Esse último encerrou a programação dos festejos pela abolição no domingo, 20 de maio, uma semana depois de assinada a lei. MORAES, Renata Figueiredo. "As festas da abolição: 013 de maio e seus significados no Rio de Janeiro (1888-1908)". (Tese de doutorado, PUC-Rio, 2012).

28 "Classe typográphica - Grande Passeata Cívica", Cidade do Rio, 19 de maio de 1888. O distintivo era formado por uma fita branca e outra preta que formariam um laço a ser localizado no ombro esquerdo de cada membro do desfile.

29 “Abolição", Revista Typographica, 26 de maio de 1888.

30 Na publicação da poesia na Revista Typographica não há o autor da obra. No entanto, o folheto dessa poesia consta na coleção de papéis distribuídos nos festejos pela abolição. Atualmente esse material faz parte do acervo do Arquivo Público Mineiro e encontra-se publicado no livro VENÂNCIO, Renato Pinto (org.). Panfletos abolicionistas. O 13 de maio em versos. Belo Horizonte: Secretaria de Estado de Cultura de Minas Gerais, Arquivo Público Mineiro, 2007. 
Nesta poesia, o jovem poeta Osório Duque-Estrada enfatiza a ideia de batalha e conquista da abolição, e não de simples dádiva e resultante da ação de alguns heróis. Aliás, se eles existissem não seriam os ilustrados defensores da liberdade, mas aqueles "que lutam e que trabalham". Por esse motivo, não se limitam a cantar uma liberdade etérea: era com atenção para os sentimentos dos "pobres e infelizes" que faziam sua festa. Essa poesia, recitada aos festeiros em meio a um préstito encabeçado por trabalhadores, exaltava a diversidade daqueles que batalharam pela abolição e que não eram os já conhecidos e louvados abolicionistas dos festejos da imprensa.

De forma distinta daquela feita pela comissão da imprensa fluminense, os tipógrafos ainda produziram e distribuíram gratuitamente um jornal comemorativo à assinatura da lei. ${ }^{31} \mathrm{O}$ título do jornal, Treze de Maio, marcava para quem o recebia o motivo de toda aquela movimentação. ${ }^{32} \mathrm{~A}$ obra, editada em cinco páginas e publicada pela mesma tipografia da Revista Typographica, tinha textos escritos pelos tipógrafos e homenageava os personagens da abolição, dando significados ao momento vivido por todos.

Esse era o sentido do texto “13 de Maio” do tipógrafo Augusto Barreto:

(...) Agora que o Brasil é iluminado pelo facho radiante da liberdade; agora que não é o mesmo sol, escurecido pelos sofrimentos da miseranda legião escrava, que nos ilumina, podemos dizer altivos e sem que a nossa face se enrubeça, que somos brasileiros.

Humilde operário, mas tendo um coração que sabe palpitar de entusiasmo pelos grandes cometimentos venho erguer também um viva aos beneméritos da grande causa da abolição! 33

A abolição, como luz radiante, além de acabar com uma escuridão, também eliminava a vergonha vivida por outros trabalhadores que, após a lei da liberdade, poderiam se classificar como brasileiros. Apesar de o autor se tratar como humilde operário e, assim, não reivindicar maiores glórias para o seu ofício, se incorpora àqueles que se entusiasmaram pela abolição e por isso acha digna sua manifestação. Essa fala representa a de milhares de outros trabalhadores que, mesmo tendo um ofício distante de ações que pudessem favorecer a abolição, naquele momento pretendiam saudá-la.

Para os tipógrafos, a abolição também marcava o início de um novo tempo no mundo do trabalho e no Império. Esse era o sentido do texto "A nova phase", assinado pelas iniciais da tipografia, H. L.:

Os que trabalham devem saudar jubilosos o grande acontecimento que acaba de dar-se. O imenso futuro que espera este país, tão divinamente dotado, está todo dependente do trabalho, e a liberdade que acaba de ser proclamada para essa possante alavanca do progresso, constitui o maior padrão de glória para o Brasil. Essa liberdade vem juntar-se àquelas de que já gozávamos pelas instituições adotadas e colocar o Império em primeiro plano, pois ficará sendo incontestavelmente a nação mais livre do mundo. ${ }^{34}$

O texto é uma ênfase sobre o efeito da lei para os demais trabalhadores. A

31 Os organizadores dos festejos publicaram um jornal comemorativo, o Imprensa Fluminense, único periódico vendido na Corte no dia 20 de maio de 1888.

32 Treze de Maio, 1888.

33 Augusto Barreto, "13 de maio", Treze de Maio, 1888.

34 H. L. "A nova phase", Treze de Maio, maio de 1888. 
abolição não afetava apenas quem era escravo, mas sim quem vivia no mundo do trabalho livre e que gozaria da glória a ser vivida pelo país e pelo Império após esse feito. A nova fase vinha do mundo comum do trabalho, ao qual todos teriam acesso através da liberdade dos escravos e que afetava diretamente seu cotidiano de trabalho. Tamanha interferência mereceu não apenas as páginas de um jornal, mas também todo um ambiente festivo programado para eles.

O jornal especial também homenageou aqueles personagens da abolição já lembrados pelos demais periódicos da Corte naqueles dias de festa. Entre eles, estavam: a Regente, o abolicionista José do Patrocínio, o poeta Castro Alves e Joaquim Nabuco, lembrados em textos específicos, e os citados no topo da página: Senador Dantas, Silveira da Mota, Angelo Agostini (Revista llustrada), Joaquim Serra (O Paiz), J. Clapp (Confederação Abolicionista), Ferreira de Araújo (Gazeta de Notícias); os republicanos Quintino Bocaiuva, Lopes Trovão, Ennes de Souza, o deputado Afonso Celso Jr., Nicolau Moreira, Ubaldino do Amaral e Campos de Paz. ${ }^{35}$

Mesmo destacando personagens comuns para a abolição, faziam isso a partir do ponto de vista dos trabalhadores que atuavam nas diferentes tipografias e que naquele momento especial se reuniam em torno de um jornal para deixar marcado para seus leitores, possivelmente seus pares, o que esperavam da abolição e quem eram os seus heróis. Logo, se a comissão da imprensa, ao fazer seu jornal comemorativo, pretendeu marcar o protagonismo dos jornais e jornalistas na festa, dando à folha lançada em meio às comemorações o título de Imprensa Fluminense, os tipógrafos pareciam mais interessados em associar seus textos à data que libertava os escravos e que incorporava o progresso à ordem do dia.

Os trabalhadores das tipografias, ao comemorarem a abolição, demonstravam ter uma visão própria e independente acerca daquele momento e seus responsáveis. O grande préstito e a publicação da folha Treze de Maio eram sinais de que mais trabalhadores participaram daquele ato não apenas como meros coadjuvantes da festa, mas como categoria organizada e com um histórico de ações abolicionistas, além de um discurso próprio a respeito da abolição.

Não por acaso, naquele mesmo ano foi criado o Centro Tipográfico Treze de Maio, fundado em 3 de junho. Nessa data, a comissão dos festejos dos tipógrafos, além de promover uma reunião para fazer um balanço das festas, definiu os princípios que regeriam o novo centro. No texto que anunciava uma reunião no dia seguinte, o editor da Revista Typographica previa que o Centro seria um local de reunião dos tipógrafos e ambiente de manifestação de um mesmo pensamento, de um programa e de uma ideia. Não só promoveria a ordenação do trabalho e de um método para as oficinas tipográficas, mas também amenizaria as desavenças existentes nas oficinas. Além de todas essas funções, caberia ainda ao novo centro celebrar anualmente a data da abolição. ${ }^{36}$ De fato, o próprio nome atribuído à instituição indicava o grande envolvimento desse grupo de trabalhadores com a lei que acabara de ser promulgada:

É um fato auspicioso e de incontestável significação e alcance a criação desse centro. É um fato auspicioso porque ele sintetiza em si uma aspiração arraigada, um pensamento tão sublime como foi o grande feito que deu origem à sua criação: a redenção do ser humano. ${ }^{37}$

35 Treze de maio, maio de 1888.

36 "Reunião Typographica”, A verdade, 9 de junho de 1888; "Reunião Typographica”, Diário de Notícias, 4 de junho de 1888.

37 “Centro Typográphico 13 de Maio”, Revista Typographica, 16 de junho de 1888. 
A criação do Centro, associada à data de promulgação da lei, deveria servir como momento de união. ${ }^{38} \mathrm{~A}$ lei inspirava os associados e a redenção proveniente dela seria inspiradora para as demais lutas dos tipógrafos. O Centro marcava a união de um grupo de trabalhadores desafiados a enfrentar as dificuldades do ofício. Assim, os tipógrafos, pertencentes a uma categoria de trabalhadores especializados, se apropriavam da abolição e dos seus sentidos, liberdade e luta, para pensar a própria categoria. As festas promovidas por eles e todas as homenagens aos abolicionistas e aos membros do Império estavam dentro de uma dinâmica de se fazerem presentes num ambiente festivo, espaço de reivindicação de novas conquistas sociais, além da própria folga para festejar.

Tipógrafos e funcionários públicos tinham, no entanto, algo em comum. Embora vivessem do seu trabalho, foi fazendo parte do mundo letrado que as duas categorias afirmavam sua identidade. A festa vivida por esses dois grupos não foi a mesma vivida pelos demais trabalhadores da Corte. O direito da folga nos dias de festa não foi algo imediato à assinatura da lei e teve que ser batalhado em outras esferas que não incluíam apenas um pedido direto para o superior, conforme fizera Artur Azevedo. Trabalhadores distantes do mundo das letras e das leis reivindicaram horas de lazer para participar da festa, apesar de serem tolhidos pelos interesses dos patrões. Diante disso, foram obrigados a criar seus próprios rituais de celebração - o que só pôde ser feito a partir de uma organização mais articulada desses trabalhadores.

\section{Os demais trabalhadores livres}

Os caixeiros, os que atuavam no comércio, não puderam participar ativamente da festa da abolição. A relação de trabalho com seus patrões, grande parte portugueses, era de dependência, uma vez que esse trabalhador era responsável por quase todo o serviço do comércio, exercendo uma longa jornada. Somado a isso, estava o fato da constante combinação entre o local de trabalho e o de moradia. Entre esses trabalhadores existia uma determinada hierarquia que era condicionada ao trabalho exercido por cada um, dando, assim, a esperança de uma possível mobilidade social, o que amenizava o duro trabalho e a profunda submissão aos patrões. ${ }^{39}$ Para além desse quadro de dependência e exploração, havia ainda a convivência dos caixeiros com os escravizados no ambiente urbano. A convivência entre esses dois grupos de trabalhadores era profunda, uma vez que muitas lojas tinham escravos ocupando funções auxiliares às do caixeiro..$^{40}$ Ou seja, o conceito de trabalhador livre num ambiente de escravidão poderia ser relativizado na medida em que as relações de trabalho fossem esmiuçadas. Não eram escravizados, mas também a liberdade não era vivida na sua integridade. Havia outras formas de escravização para além da tradicional abolida em 13 de maio.

Diante desse quadro de dependência e convivência entre liberdade e escravidão, a lei da abolição pretendia ser comemorada por todos, até mesmo pelos caixeiros que, apesar de livres, se sentiam presos ao seu trabalho. 0

38 Grande parte das associações existentes era destinada a oferecer socorros mútuos aos seus associados. VITORINO, "Os sonhos dos tipógrafos na corte imperial brasileira", p. 170.

39 POPINIGIS, Fabiane. Proletários de casaca. Trabalhadores do comércio carioca (1850-1911). Campinas: Editora da Unicamp, 2007, p. 34-36.

40 MARZANO, Andrea. Cidade em Cena. O ator Vasques, o teatro e o Rio de Janeiro (1839-1892). Rio de Janeiro: Folha Seca, 2008, p. 43. 
ambiente festivo da liberdade, além da lei ter sido assinada num domingo, eram oportunidades ideais para a continuidade de uma luta por folga aos domingos e mais direitos ao lazer por parte desses trabalhadores livres. ${ }^{41}$

Naquele tempo de festa, uma contradição se fazia gritante. Ao mesmo tempo em que havia uma convocação por parte dos jornais que organizaram os festejos para que os empregados do comércio aderissem às manifestações comemorativas, ${ }^{42}$ nos dias da festa o que aparecia nos jornais era uma denúncia feita pelo próprio editor a respeito do não fechamento do comércio e a ausência desses trabalhadores nas comemorações. Afinal, aquele tempo de festa era também de negócios para esse comércio.

É muito justo e muito regular o que vamos solicitar do comércio da Corte, esta classe tão distinta pelo seu patriotismo e por seu critério - que feche os seus estabelecimentos durante os festejos populares.

Os moços empregados do comércio desejam também levar o contingente de suas alegrias às públicas manifestações que se consagram à lei da extinção do elemento servil, e por isto nos pedem para reclamar para eles esta concessão, obtendo que o comércio em geral feche os seus estabelecimentos, durante os dias dos festejos, ao menos das duas horas da tarde em diante. ${ }^{43}$

Mesmo não sendo um apelo para a presença dos empregados do comércio durante todo o dia de festejo, ainda assim é uma lembrança de que os estabelecimentos comerciais deveriam conciliar diferentes interesses: o da venda de produtos e da folga para os empregados. Um exemplo da movimentação que essas mesmas festas faziam no comércio está esse anúncio publicado em dois jornais no mesmo dia.
Abolição
Alugam-se, para as grandes festas da libertação dos escravos, bandei- ras, sinais, galhardetes, mastros, cadeiras austríacas, colchas de damas- co de seda de todas as cores, cortinas, reposteiros, arandelas, placas, serpentinas, candelabros, jarras, espelhos, talheres de Christofle, glo- bos e muitos outros objetos próprios para bailes, casamentos e outras festas, na antiga casa do castelo, à Rua dos Inválidos, n. $41 .^{44}$

As festas eram momentos de consumo e as casas que vendiam objetos decorativos, vestidos e outros acessórios deveriam estar abertas para serem visitadas por aqueles que participariam das festas de gala ou que pretendessem enfeitar suas fachadas. A abolição era uma oportunidade de negócios e que não deveria ser perdida. Isso explica o investimento do dono desse estabelecimento na publicação do anúncio em dois jornais de grande circulação. A demanda por esses objetos anunciados evidencia a diversidade de público nas festas e as possibilidades que poderiam existir para comemorar a abolição. O mesmo ocorreu com os vestidos e as possibilidades que as damas da sociedade teriam para usá-los nesses dias de festa.

\footnotetext{
41 POPINIGIS. Proletários de casaca, p. 108. A primeira reivindicação pelo fechamento do comércio aos domingos apareceu na década de 1850, mas apenas em 1911 houve um decreto da Câmara Municipal regulamentando o trabalho no comércio.

42 "Imprensa Fluminense", Gazeta de Notícias, 16 de maio de 1888.

43 “Reclamação", Diário de Notícias, 18 de maio de 1888. No dia seguinte, o jornal voltou a publicar uma nota pedindo a liberação.

44 Diário de Notícias e Gazeta de Notícias, 17 de maio de 1888.
} 


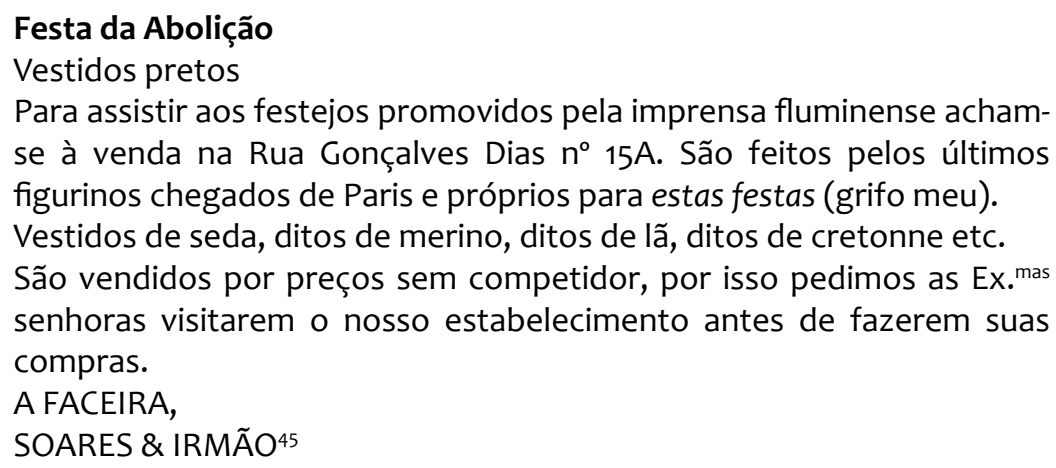

Interessante notar que os trajes para "estas festas" eram vendidos na loja vizinha à Revista llustrada, ${ }^{46}$ na Gonçalves Dias. Tanto esta rua, como a dos Inválidos, receberam um grande contingente de pessoas desde o anúncio da abolição e isso só aumentaria com o início dos festejos da imprensa. Sendo assim, nada mais natural que essas lojas permanecessem abertas, exibindo figurinos para um público que, ao mesmo tempo em que prestasse homenagens à Revista llustrada, por exemplo, pudesse também conferir a última moda em Paris. A grandiosidade dos festejos da imprensa parecia pedir tamanho investimento. Como fechar o comércio diante de tantas possibilidades de negócio? Quem trabalhava nessas lojas não poderia festejar a liberdade.

Diante de tamanha impossibilidade de folga, esses trabalhadores recorreram à imprensa, promotora das comemorações, para garantir sua participação. Esse ato não era, no entanto, novidade para os comerciários. Desde a primeira reivindicação feita por folga aos domingos, em 1852, os jornais foram utilizados como meio de pedir o apoio de políticos e, assim, pressionar as esferas superiores para que regulassem o trabalho no comércio. ${ }^{47} \mathrm{O}$ mesmo tipo de estratégia era usado tradicionalmente pelos caixeiros em relação ao poder Legislativo. ${ }^{48}$ No momento da festa pela abolição, tanto a imprensa quanto os legisladores foram solicitados a fim de que contribuíssem para a conquista dos caixeiros. Um desses casos foi dos empregados do prédio da Praça do Mercado, próximo à Rua do Ouvidor, ao pedirem a intervenção do vereador José do Patrocínio para que o prédio fosse fechado e os empregados liberados para o festejo da abolição. A "ajuda" de Patrocínio foi publicada em seu jornal e foi considerada "mais um ato de liberdade" promovido por ele, numa referência à sua posição abolicionista. ${ }^{49}$ Ou seja, uma luta histórica dos caixeiros pelo fechamento do estabelecimento comercial era associada a outra, a da liberdade dos ex-escravos. Aqueles que haviam batalhado no Parlamento e na imprensa pela liberdade dos cativos eram capazes, então, de continuar a lutar por outra liberdade: a de folga para o festejo. Essa era mais uma etapa do processo de regulação do trabalho livre que com a abolição se acirrava ainda mais. Ao lado dos escravos estavam os abolicionistas e após o fim da escravidão, quem seriam os defensores, na imprensa, da regulação e ordenamento do trabalho? Essa foi uma questão de difícil resposta logo naquele maio de 1888.

45 Gazeta de Notícias, 18 de maio de 1888.

46 A redação da Revista llustrada ficava no número 50 da Rua Gonçalves Dias.

47 POPINIGIS. Proletários de casaca, p. 112.

48 No início da década de 1880, houve uma conquista por parte dos trabalhadores do comércio pela folga aos domingos. Porém, essa conquista durou apenas alguns meses e a medida foi revogada pela própria Câmara, que a havia implantado por conta das pressões dos empregadores. SOUZA, Juliana Teixeira. "A Autoridade Municipal na Corte Imperial: enfrentamentos e negociações na regulação do comércio de gêneros (1840-1889)". (Tese de doutorado, Unicamp, 2007), p. 115.

49 Cidade do Rio, 19 de maio de 1888. 
Os caixeiros não estavam sozinhos no uso da imprensa para reivindicar folgas. Usando do mesmo artifício estavam também os empregados das chapelarias que pediram o fechamento total da fábrica de chapéus nos últimos dias da semana, exatamente nos dias de festa da imprensa. ${ }^{50}$ Além deles, os funcionários da Caixa Econômica denunciaram que eles não haviam sido contemplados pelo feriado decretado por diversas repartições públicas. O argumento para o fechamento era baseado no fato de que dificilmente haveria quem fosse depositar dinheiro no banco nos dias da festa..$^{11}$ Ao reivindicarem publicamente uma chance de participação efetiva na festa da liberdade, saudada nos jornais como uma festa de todos, essas três categorias de trabalhadores (comerciários, chapeleiros e bancários) evidenciavam o quanto era restrita, na prática, a abrangência dessas comemorações preparadas pelos jornais para representar a alegria de todos. Ao mesmo tempo, faziam do discurso da imprensa um meio de alimentar suas próprias lutas - evidenciando a tentativa de fazer do momento da abolição mais uma oportunidade para a continuidade das reivindicações por melhores condições de vida e de trabalho e, por que não, por horas de lazer.

Essa luta pela participação nas festas aproximava-se, desse modo, de antigas reivindicações desses trabalhadores que mostravam fazer desse momento uma oportunidade de legitimação das causas e aspirações que organizavam sua luta, como, por exemplo, a continuidade no pedido de folga aos domingos e nos dias santos..$^{52}$ Os caixeiros são exemplo da existência de demandas próprias durante e depois da escravidão que, de alguma forma, se assemelham no que tange à conquista de direitos e benefícios no mundo do trabalho para além da dicotomia escravo/livre. ${ }^{53} \mathrm{~A}$ luta por espaços de liberdade, promovida tanto por trabalhadores escravos como por livres, certamente foi alimentada pela troca de experiências coletivas ou individuais entre esses diversos ofícios que em maio de 1888 se tornaram um só: trabalhadores. ${ }^{54} \mathrm{Em}$ maio de 1888 , o ambiente festivo e de celebração da liberdade tendia a ser compartilhado por todos eles uma vez que agora passariam a lutar juntos por uma mesma causa: a regulamentação do trabalho.

Por mais que os organizadores dos festejos tivessem um discurso de união e suspensão das atividades nos dias pós-assinatura da lei - ou seja, toda a cidade pararia para comemorar a abolição -, de fato isso não ocorreu. Os espaços para os festejos estavam abertos para aqueles que já viviam num ambiente onde a possibilidade de negociação já era estabelecida. Nessa negociação, tipógrafos e funcionários públicos, como os do Ministério da Agricultura, formaram um grupo de trabalhadores privilegiados, que puderam assim, de modo distinto, conquistar espaço nas festas. Ou seja, já viviam num ambiente letrado e de fácil negociação, distinto das demais categorias de trabalhadores da cidade, como caixeiros, funcionários das estradas de ferro e até mesmo outros funcionários públicos como os da Caixa Econômica e os da Câmara Municipal, que não receberam folga de imediato. Esses tiveram que se contentar com outros festejos.

Este texto pretendeu pensar o trabalho livre no Brasil no momento seguinte ao do fim da escravidão. Trabalho livre que ainda não abrangia os ex-escravos, mas

50 Diário de Notícias, 18 de maio de 1888.

51 Gazeta de Notícias, 18 de maio de 1888.

52 POPINIGIS. Proletários de casaca, p. 120. Muitas vezes, os trabalhadores utilizavam argumentos cristãos. Na República, essa reivindicação vai ser pelo limite de 12 horas de trabalho.

53 MATTOS, Marcelo Badaró. Trabalhadores e sindicatos no Brasil. São Paulo: Expressão Popular, 2009, p. 17.

54 Silvia Lara em seu texto sobre esses diferentes "mundos" do século XIX propõe a busca por experiências coletivas ou individuais entre trabalhadores escravos e livres. LARA, Sílvia Hunold. "Escravidão, cidadania e história do trabalho no Brasil”. Projeto História: PUC-SP, n. 16, fev. 1998. 
sim trabalhadores livres e pobres e outros letrados. Trabalhadores que viveram a dicotomia trabalho livre/escravo e que testemunharam as mudanças vindas com a abolição. A liberdade dos escravos os afetaria de algum modo. Seja no dia a dia da cidade ex-escravista ou nas outras formas de reivindicar melhorias nas condições de trabalho. De qualquer modo, comemorar a abolição para esse grupo tão heterogêneo que tendemos a homogeneizar sob uma mesma palavra, a de trabalhadores, significou conquistar espaço numa festa que parecia de poucos apesar do seu motivo muito mais amplo. A abolição inaugurava um novo tempo até para aqueles que não tinham vivido na própria pele a escravidão.

Recebido em 13/06/2015 Aprovado em 26/10/2015 
